\title{
Tanzanian mushrooms and their uses 4. Some reddish edible and poisonous Amanita species
}

\author{
MARJA HÄRKÖNEN, TIINA SAARIMÄKI and LEONARD MWASUMBI
}

\begin{abstract}
HÄRKÖNEN, M., SAARIMÄKI, T. \& MWASUMBI, L. 1994: Tanzanian mushrooms and their uses 4. Some reddish edible and poisonous Amanita species. - Karstenia 34:47-60. Helsinki. ISSN 0453-3402

Three new species of Amanita, section Vaginatae, are described from Tanzania: A. tanzanica Härk. \& Saarim., A. masasiensis Härk. \& Saarim. and A. mafingensis Härk. \& Saarim. These species are related to $A$. hemibapha (Berk. \& Br.) Sacc., the tropical relative of $A$. caesarea (Scop. : Fr.) Pers. All the new species are considered edible by the local people and have a collective vernacular name in each tribe. They are often confused with the poisonous $A$. muscaria (L.: Fr.) Pers., which is abundant in exotic pine plantations, and mushroom poisonings, even fatal ones, occur.
\end{abstract}

Key words: Africa, Amanita, edible mushrooms, ethnomycology, poisonous mushrooms, Tanzania, taxonomy

Marja Härkönen and Tiina Saarimäki, Department of Botany, P.O. Box 7, FIN-00014 University of Helsinki, Finland

Leonard Mwasumbi, Department of Botany, University of Dar es Salaam, P.O. Box 35060, Dar es Salaam, Tanzania

\section{Introduction}

This article is part of a series of studies dealing with edible mushrooms of Tanzania. The research area, methods, and some results were introduced in our previous articles (Härkönen 1992, Härkönen et al. 1993a-c, Saarimäki et al. 1994).

During the collecting trips in miombo woodlands, primarily in the southern and southwestern parts of Tanzania, we could observe people collecting several species of Amanita for food. In this article we concentrate on annulate, vaginate Amanita species with a reddish (orange to brownish) pileus.

These edible species of Tanzanian Amanita were easy to identify to section Vaginatae (Fr.) Quél. (see Jenkins 1986) and were similar to the famous Amanita caesarea (Scop.: Fr.) Pers., which is a well-known delicacy used and sold in southern Europe since antiquity. Even the original boletus of the ancient Romans was not a boletaceous mushroom, but A. caesarea (Singer 1975).

Amanita hemibapha (Berk. \& Br.) Sacc., first described from Sri Lanka (Berkeley \& Broome
1871), is a tropical relative of $A$. caesarea. The description is brief and does not contain any microscopy. A beautiful colour plate is included, clearly showing a scarlet pileus with a yellow, deeply sulcate margin and a yellow ring and gills. Corner \& Bas (1962) summarize the characteristics of A. hemibapha as follows: "Amanita hemibapha, extremely variable as to the colour of the pileus, is recognizable by (i) the yellow stipe with sometimes concolorous, but mostly brighter coloured appressed fibrillose scales, (ii) the yellow to yellowish gills with brighter coloured edge, (iii) the attenuate base of the stipe, (iv) the white to greyish deeply sheathing rather fleshy volva, attached only to the extreme point of the base of the stipe and (v) the tropical distribution."

Corner \& Bas (1962) divide Amanita hemibapha into three subspecies according to their colour: subsp. hemibapha has a crimson red pileus with a yellow margin, subsp. javanica Corner \& Bas has an orange yellow to ochre yellow pileus with a yellow margin, and subsp. similis (Boed.) Corner \& Bas has a fuliginous bistre to brownish 
olivaceous pileus with a yellowish to melleous margin. All the subspecies have yellow and scaly stipe with a ring of different tones of yellow.

Our Tanzanian material can be divided into three groups: 1) those with an orange-yellow pileus and bright yellow gills, stipe, and ring, 2) those with a chestnut pileus and pale yellow gills, stipe, and ring, 3) those with a bright orange pileus and white gills, stipe, and ring. All the specimens have a deeply saccate white volva. Macroscopically the first two groups resemble $A$. hemibapha subsp. javanica and subsp. similis respectively, but the third differs from $A$. hemibapha in its absolutely white gills, stipe, and ring.

After examining the specimens of Amanita hemibapha, and the photos (including the two unpublished plates referred to in Corner \& Bas 1962: 296) kindly sent to us by C. Bas, we found that the Tanzanian specimens have more in common with each other than with $A$. hemibapha, and thus they have to be described as new species.

\section{Material and methods}

The specimens studied were collected in central and southern Tanzania. Collecting sites are according to Polhill (1988) and Leistner \& Morris (1976). All specimens are deposited at the Botanical Museum of the University of Helsinki $(\mathrm{H})$ with the collecting number under the title Saarimäki et al. and some representative specimens in the Herbarium of Dar es Salaam (DSM). All the authors have taken part in the collecting and interviewing of local people, Härkönen being the director responsible for the project. The microscopic examination and measurements were done and the text was written mainly by Härkönen. Mwasumbi was responsible for the identification of the host trees and for interpreting conversations with local people. Saarimäki assisted in preparing the final version of the article. The photographs are by the first two authors, and drawings by the first author.

Hand sections for microscopic examinations were mounted in different chemical reagents. Congo Red and Cotton Blue were used for measuring basidia, basidiospores, hyphae and inflated cells, whereas Meltzer's Reagent was for testing the chemical reaction of basidiospores.

Spores were studied from spore prints or from small segments of gills. In the description the range of spore size and the arithmetical mean is based on 20 fully developed spores of each specimen. $\mathrm{Q}=$ quotient of the mean spore length and the mean spore width (L/W ratio).

\section{Description of new species}

Amanita tanzanica Härk.\& Saarim., sp. nova - Figs. 1-4

Pileus $5-11 \mathrm{~cm}$ in diametro, laete vel saturate aurantiacus, superficie laevi, sericea, viscida, margine striata. Lamellae liberae, albae, sat tenues et admodum crebrae. Stipes $8-13 \mathrm{~cm}$ longus, $1-1.5 \mathrm{~cm}$ latus, aequicrassus, basi aliquot attenuatus, albus. Annulus superus, albus, tenuis, pendulus, subtiliter striatus. Volva tantum ad basim stipitis affixa, alba, magna, saccata, crassa, lobata. Medulla alba, sub pellicula flava, medulla stipitis postremo cava. Odor infirmus terrenus. Sapor mitis, gratus. Pulvis sporarum albus.

Sporae hyalinae, inamyloideae, laeves, 8.5$\underline{10.45}-12.5 \mu \mathrm{m}$ longae, 5.5- $\underline{6.61}-8 \mu \mathrm{m}$ latae, $\mathrm{Q}=$ 1.48-1.58-1.72. Basidia quadrispora, clavata, 30-45 $\mu \mathrm{m}$ longa, 9-13 $\mu \mathrm{m}$ lata. Acies lamellarum sterilis. Medulla ubique hyphas lactiginosas continens.

Type: Tanzania. Southern Prov.: Tunduru Distr., 18 $\mathrm{km} \mathrm{W}$ of Tunduru (10 $37 \mathrm{CC}$ ), miombo woodland with Brachystegia, Pterocarpus, Xeroderris, Diospyros, Diplorhynchus, and Albizia, 600 m, 25.I.1993 Saarimäki et al. 1388 (holotype, H).

Pileus $5-11 \mathrm{~cm}$ in diameter, first convex, becoming flat; bright orange to dark orange becoming paler and having more ochre tint with age; surface smooth, sticky, striate $5-10 \mathrm{~mm}$ at margin, seldom with one or few large, white patches of veil remnants. Lamellae free, white, fairly crowded and fairly thin, 5-9 mm wide, edge smooth and concolorous. Stipe $8-13 \mathrm{~cm} \times$ (0.5)-1-1.5(-2) cm, white, cylindrical, but extreme base slightly attenuate; above annulus finely striate, below annulus slightly floccose. Annulus white, thin, superior, hanging, finely plicate. Volva attached to extreme point of stipe, white to dirty white, large, saccate, lobed, thick, slightly floccose outside, smooth inside with a small limbus internus. Context in cap fairly firm, white, yellowish under pellicle; in stem white, brittle and fibrous, later hollow and floccose. Smell weakly earth-like. Taste mild, pleasant. Spore print white.

Spores hyaline, inamyloid, ellipsoid to elongate, smooth with usually one large, sometimes with few guttules, 8.5-10.45-12.5 × 5.5- $\underline{6.61-}$ $8 \mu \mathrm{m}, \mathrm{Q}=1.48-1.58-1.72$. Basidia 4-spored, 

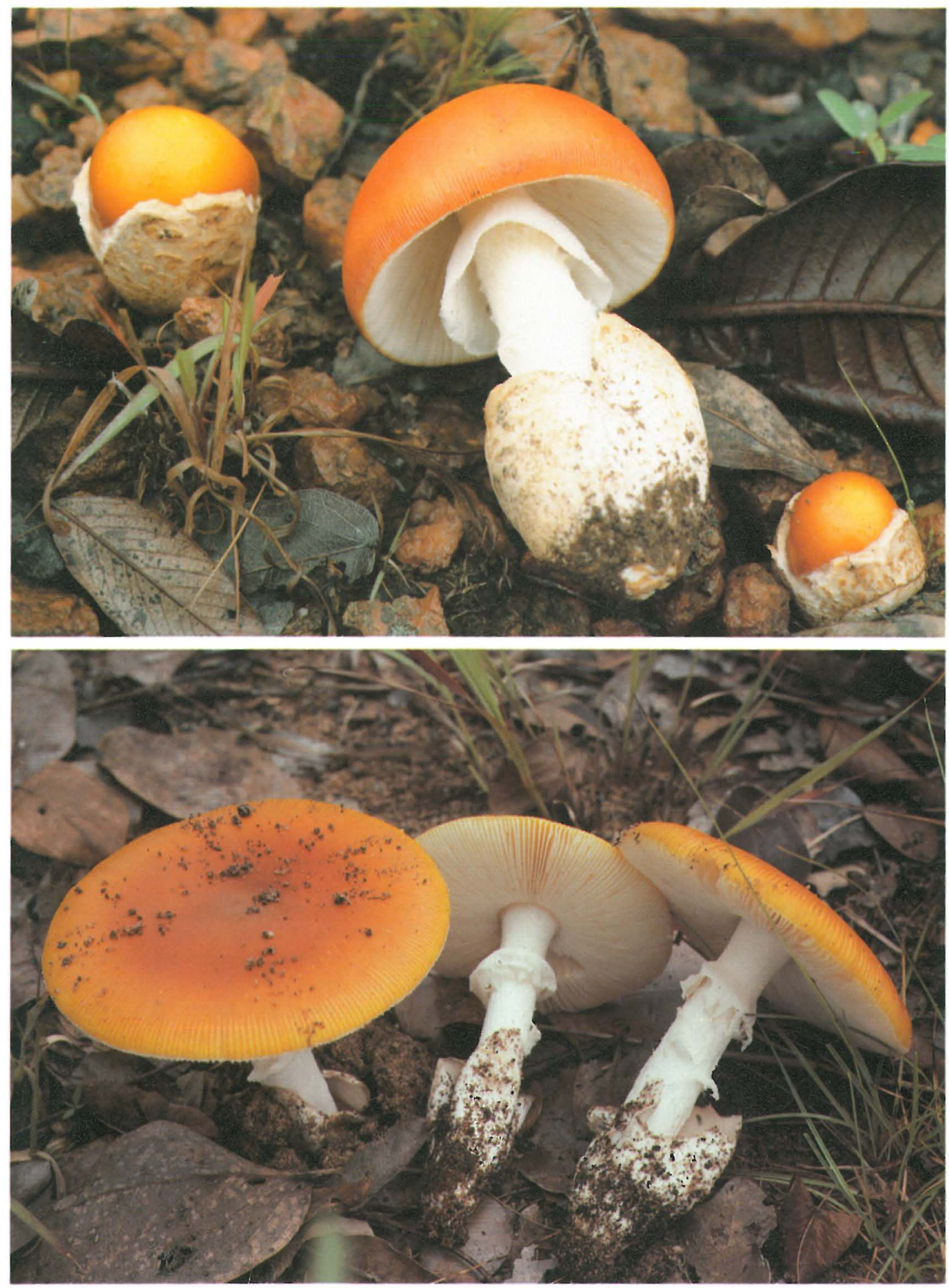

Figs. 1-2. Amanita tanzanica with white stipe, gills, and annulus. - 1: Young fruit bodies (1483). - 2: Fruit bodies of type specimen (1388). 


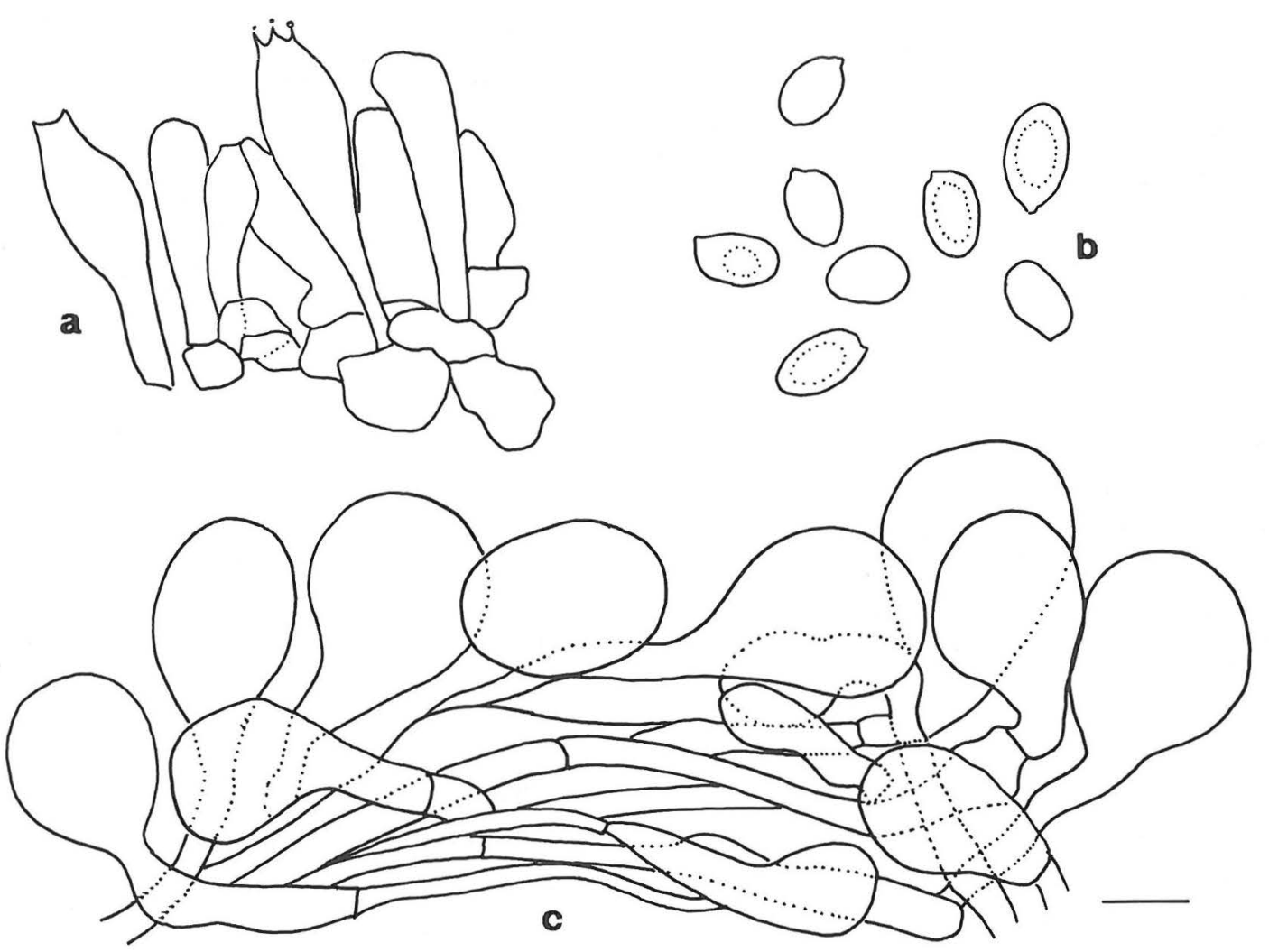

Fig. 3a-c. Amanita tanzanica (type). - a) hymenium, b) spores, c) tissue on sterile gill margin. Bar $=10 \mu \mathrm{m}$.

club-shaped, 30-45 × 9-13 $\mu \mathrm{m}$ (only mature ones with sterigmata measured), basidioles shorter. Hymenophoral trama bilateral. Subhymenium of irregularly subglobose to angular cells, $5-15 \mu \mathrm{m}$ in diameter. Gill margin sterile; marginal cystidia-like cells 30-70 $\mu \mathrm{m}$ long. Surface of pileus strongly gelatinized in its upper part with fading repent hyphae $2-5 \mu \mathrm{m}$ in diameter, mostly without but occasionally with clamps. Conspicuous vascular hyphae up to $10 \mu \mathrm{m}$ in diameter penetrate the surface tissue. Stipe trama acrophysalidic, at surface of partially gelatinized, longitudinally parallel hyphae with some inflated cell-endings; inside of long, flexuous, loose hyphae, 4-7 $\mu \mathrm{m}$ in diameter, occasionally having clamps and plenty of inflated subglobose to club-shaped cell-endings of variable size up to $150 \mu \mathrm{m}$ long and $50 \mu \mathrm{m}$ wide. In all parts of the stipe long vascular hyphae up to $15 \mu \mathrm{m}$ in diameter can be found. Volva so strongly gelatinized inside that individual hyphae hardly distinguishable, outside less gelatinized with interwoven hyphae $1.5-6 \mu \mathrm{m}$ in diameter, often with vascular hyphae, but only seldom with inflated cells. Annulus of interwoven hyphae, partially gelatinized, with few vascular and few inflated cells.

Ecology. Amanita tanzanica grows in miombo woodland at altitudes from about 300 to $1650 \mathrm{~m}$. It is evidently mycorrhizal with several indigenous miombo tree species. From the 22 tree genera listed from the growing sites, Uapaca, Brachystegia and Parinari were most often present.

\section{Specimens examined}

Tanzania. Southern Prov.: Masasi Distr., $60 \mathrm{~km} \mathrm{SW}$ of Masasi, Kigweje village (10 $38 \mathrm{CD}$ ), in field under Anacardium, 300 m, 24.I.1993 1375. Tunduru Distr., Kingulungulu village (10 37 CD), on the way to Tunduru, purchased from a woman carrying a basket containing many species of edible mushrooms, $500 \mathrm{~m}$, 24.I.1993 $1378 ; 18 \mathrm{~km} \mathrm{~W}$ of Tunduru (10 $37 \mathrm{CC})$, miombo woodland with Brachystegia, Pterocarpus, Xeroderris, Diospyros, Diplorhynchus, and Albizia, 600 m, 25.I.1993 1385; holotype $1388 ; 114 \mathrm{~km} \mathrm{~W}$ of Tunduru, highest point along main road (10 36 DA), 800 m, 25.I.1993 1394. Songea 

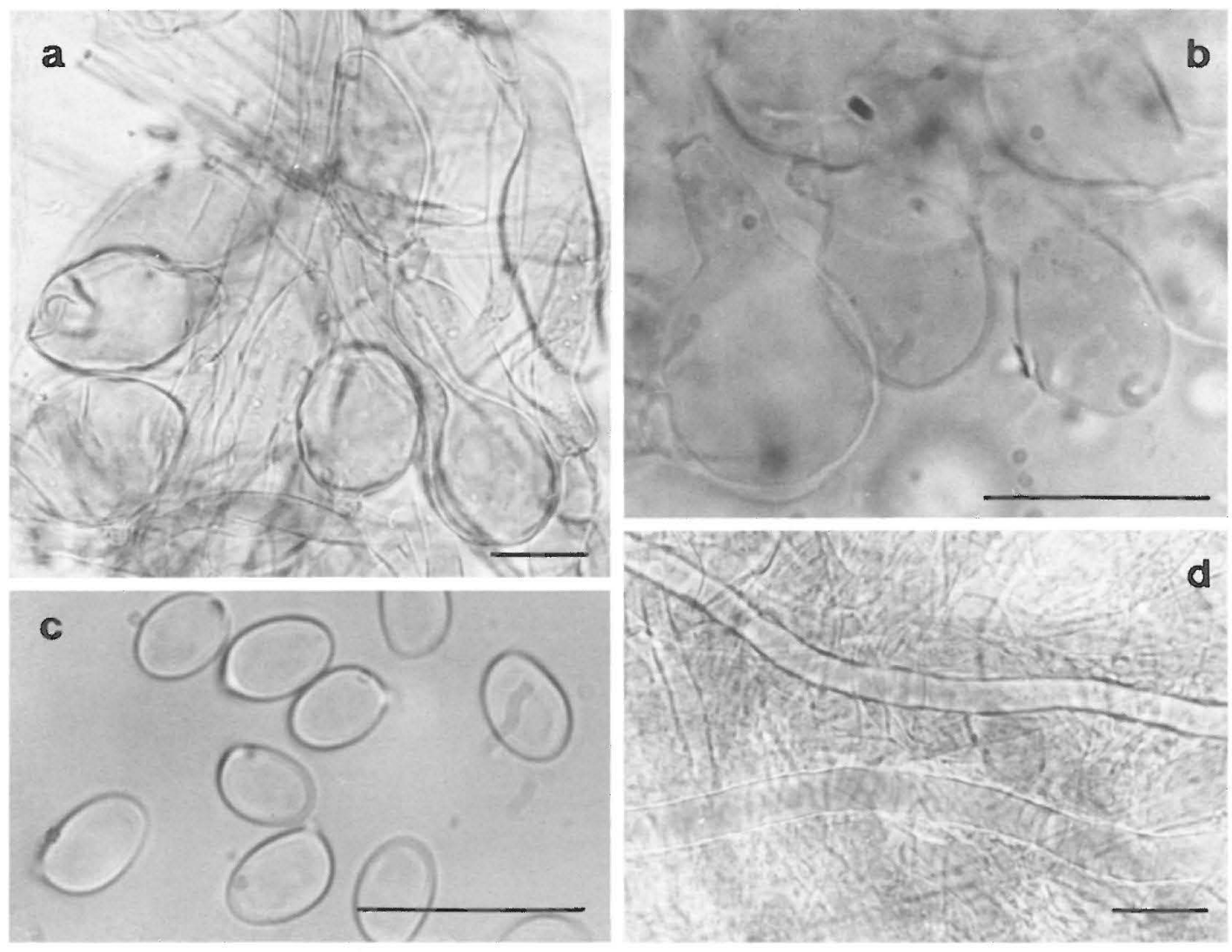

Fig. 4a-d. Microscopic details of described species. - a) inflated cells inside stipe of Amanita tanzanica 1431, b) cystidialike cells on gill margin of $A$. tanzanica, c) spores of $A$. mafingensis $1476, \mathrm{~d})$ vascular hyphae in stipe of A. tanzanica. Bar $=20 \mu \mathrm{m}$.

Distr., near Namtumbo, Mambura village (10 36 AC), miombo with Uapaca, Syzygium, Terminalia, and Parinari, brown soil, $750 \mathrm{~m}, 26 . \mathrm{I} .1993$ 1403; $40 \mathrm{~km} \mathrm{~N}$ of Songea, Hanga, Nyamagoma village (10 $35 \mathrm{BC}$ ), miombo woodland, main trees Uapaca and Faurea, also some Parinari, 990 m, 27.I.1993 1431; 29 km from Songea towards Mbinga, Matomondo (1035 CB), degraded miombo woodland with Brachystegia, Julbernardia, Uapaca, Syzygium, and Combretum, 800 m, 29.I.1993 1442. Southern Highlands Prov.: Njombe Distr., $2 \mathrm{~km} \mathrm{~N}$ of Kidugala, Ngaramiro (09 34 BA), Brachystegia-Uapaca woodland with Ochna, Parinari, Rothmannia, Combretum molle, Garcinia, and Gardenia, on hill slope, red soil, 1550 m, 31.I.1993 1483; $11 \mathrm{~km} \mathrm{~S}$ of Kidugala, Mbalali village (09 $34 \mathrm{BA}$ ), degraded Uapaca woodland on riverside with few Brachystegia, Garcinia, Eriosema, Ochna, Faurea, Bridelia, and Protea, red soil, 1650 m, 1.II.1993 1501; N of Kidugala, between villages of Sengele and Masaulwa (09 34 BA), heavily grazed and degraded Brachystegia-Uapaca woodland, 1500 m, 2.II.1993 1526.
Amanita masasiensis Härk. \& Saarim., sp. nova - Figs. 5, 7

Pileus $3-7 \mathrm{~cm}$ in diametro, luteo-aurantiacus, parte media fere coccineus, superficie laevi, viscida, margine striata. Lamellae liberae, luteolae, sat tenues et admodum crebrae. Stipes 6-7 cm longus, $0.9-1.1 \mathrm{~cm}$ latus, flavus, aequicrassus, plus minusve lanuginosus. Annulus superus, laete luteoaurantiacus, pendulus, subtiliter striatus. Volva tantum ad basim stipitis affixa, alba, magna, saccata. Medulla pilei alba, sub pellicula lutea et juxta lamellas lutescens, medulla stipitis postremo flocculosa vel cava. Odor proprius nullus. Sapor mitis. Pulvis sporarum albus.

Sporae hyalinae, inamyloideae, laeves, 8.5$\underline{10.02}-12 \mu \mathrm{m}$ longae, 6-6.27-9 $\mu \mathrm{m}$ latae, $\mathrm{Q}=$ 1.20-1.36-1.50. Basidia quadrispora, clavata, 35-50 $\mu \mathrm{m}$ longa, 8-15 $\mu \mathrm{m}$ lata. Acies 


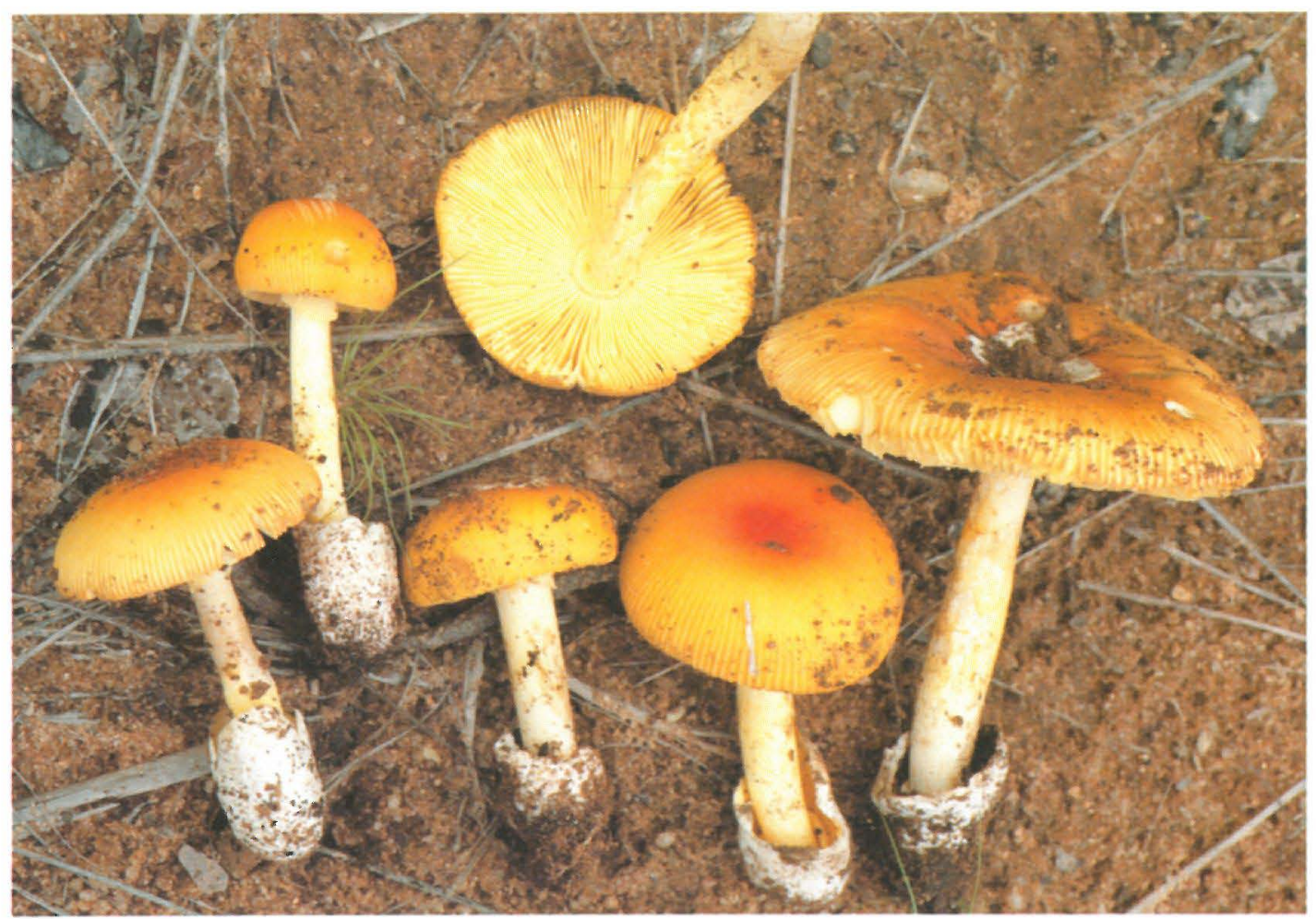

Fig. 5. Amanita masasiensis (type) with yellow stipe, gills, and annulus. Note small limbus internus in fruit body second from right.

lamellarum sterilis. Medulla ubique hyphas lactiginosas continens.

Type: Tanzania. Southern Prov.: Masasi Distr., $60 \mathrm{~km}$ SW of Masasi, Kigweje village (10 $38 \mathrm{CD}$ ), in field under Anacardium, 300 m, 24.I.1993 Saarimäki et al. 1376 (holotype, H).

Pileus $3-7 \mathrm{~cm}$ in diameter, first convex, becoming flat; yellow orange, darker and redder at center; surface smooth, slightly sticky, striate 6$13 \mathrm{~mm}$ from margin towards centre, sometimes with few white patches of veil remnants attached. Lamellae free, yellow, fairly crowded and thin, 4-6 mm wide, edge smooth and concolorous. Stipe 6-7 $\times 0.9-1.1 \mathrm{~cm}$, yellow, cylindrical, surface more or less fluffy. Annulus orange-yellow, thin, superior, hanging, slightly plicate, in specimen 1398 upper surface white, underneath yellow. Volva attached to extreme end of stipe, white, high and broad, saccate, somewhat floccose outside, inside smooth, with a limbus internus. Context in cap white, strongly yellow- ish under pellicle and somewhat yellowish also above lamellae, soft to firm; in stem white, yellowish under surface, brittle-fibrous, later hollow or stuffed inside. Smell indistinct. Taste mild. Spore print white.

Spores hyaline, inamyloid, ellipsoid, smooth, mostly with one big guttule, 8.5-10.02-12 × 66.27-9 $\mu \mathrm{m}, \mathrm{Q}=1.20-1.36-1.50$. Basidia 4spored, club-shaped, 35-50 × 8-15 $\mu \mathrm{m}$. Subhymenium of irregularly subglobose to angular cells $5-20 \mu \mathrm{m}$ in diameter. Gill margin sterile; marginal cystidia-like cells $25-55 \mu \mathrm{m}$ in length. Surface of pileus strongly gelatinized with thin, repent hyphae and with some prominent vascular hyphae. Stipe trama of partially gelatinized, longitudinally parallel acrophysalidic tissue; floccose surface of stipe made of loose hyphae and big subglobose inflated cells up to $50 \times$ $70 \mu \mathrm{m}$ in diameter; stuffed inside of stipe similar to surface. Volva outside consist of interwoven hyphae with some vascular hyphae and some inflated cells, inside strongly gelatinized. Annulus of interwoven hyphae, partially gelatinized 


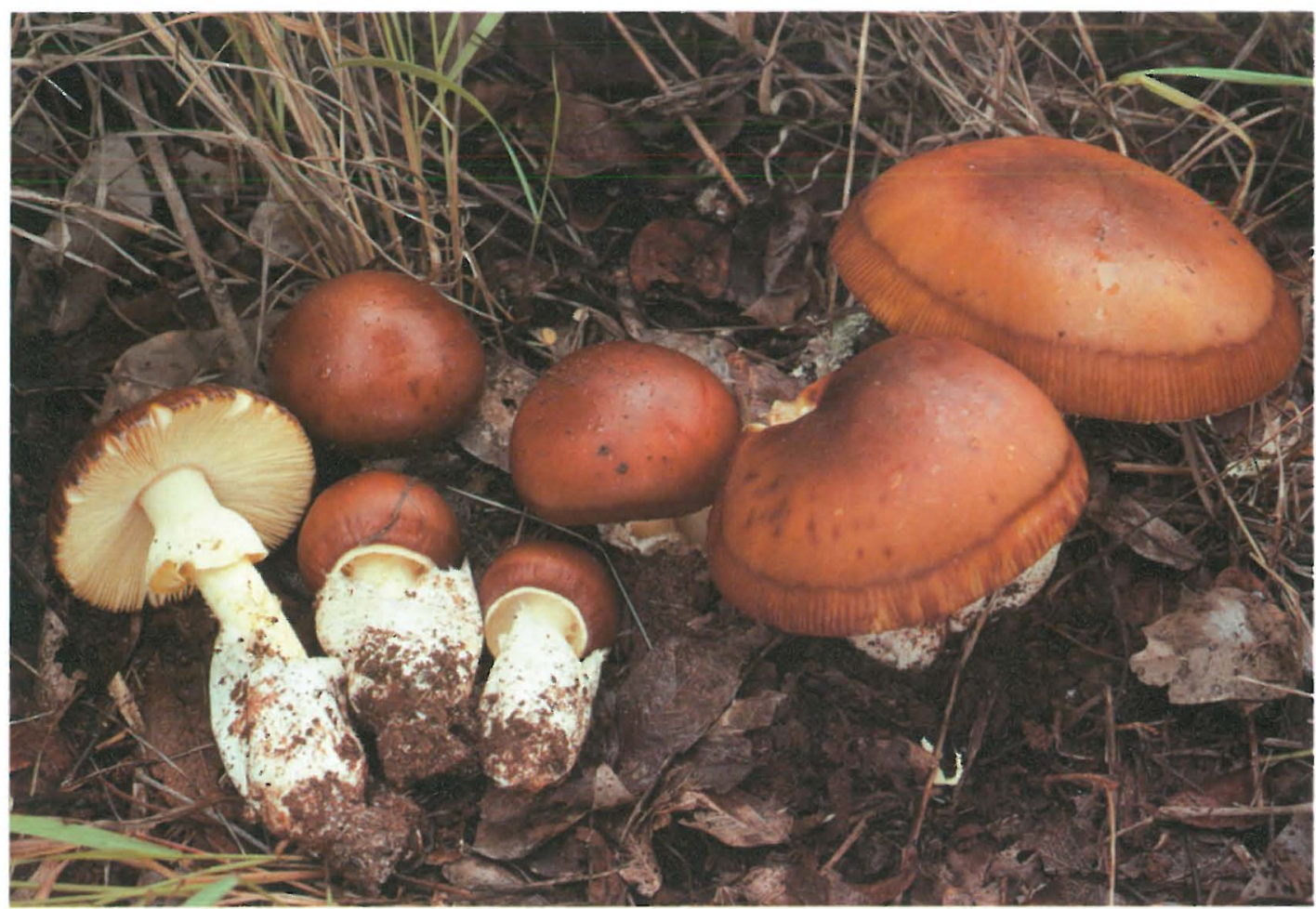

Fig. 6. Amanita mafigensis (1476) with brownish pileus and light yellow stipe, gills, and annulus.

with some vascular hyphae and some inflated cells.

Etymology: The epithet masasiensis refers to Masasi, the collection site of the type material in Tanzania.

Ecology. Miombo woodland at an altitude of 300$1000 \mathrm{~m}$, most probably mycorrhizal with several indigenous trees, Uapaca and Brachystegia being most often present. Once found in a plantation of Anacardium.

\section{Specimens examined}

Tanzania. Southern Prov.: Masasi Distr., holotype 1376. Songea Distr., near Namtumbo, Lilunde village (10 36 AC), Brachystegia-Uapaca woodland, brown soil, $700 \mathrm{~m}$, 26.I.1993 1398; 40 km N of Songea, Hanga, Nyamagoma village (10 $35 \mathrm{BC}$ ), miombo woodland, main trees Uapaca and Faurea, also some Parinari, 900 m, 27.I.1993 1433; $29 \mathrm{~km}$ from Songea towards Mbinga, Matomondo (10 35 $\mathrm{CB}$ ), degraded miombo woodland with Brachystegia, Julbernardia, Uapaca, Syzygium, and Combretum, $800 \mathrm{~m}$, 29.I.1993 1444.
Amanita mafingensis Härk. \& Saarim., sp. nova - Figs. 4, 6, 8

Pileus $4-13 \mathrm{~cm}$ in diametro, cupreo-brunneus vel badius, superficie laevi, sericea, viscida, margine striata. Lamellae liberae, eburneae vel flavescentes, sat tenues et admodum crebrae. Stipes 5-11 cm longus, 1-2 cm latus, aequicrassus, pallide flavescens vel flavus. Annulus superus, flavescens, tenuis, pendulus, subtiliter striatus. Volva tantum ad basim stipitis affixa, alba vel cinerascens, magna, saccata, lobata. Medulla pilei alba, sub pellicula lutea, medulla stipitis postremo cava. Odor infirmus cellae terrenae. Sapor mitis. Pulvis sporarum albus.

Sporae hyalinae, inamyloideae, laeves, 9.510.55-13 $\mu \mathrm{m}$ longae, 5.5-6.87-8.5 $\mu \mathrm{m}$ latae, $\mathrm{Q}=$ 1.44-1.53-1.66. Basidia quadrispora, clavata, 30 $50 \mu \mathrm{m}$ longa, 9-12 um lata. Acies lamellarum sterilis. Medulla ubique hyphas lactiginosas continens. 


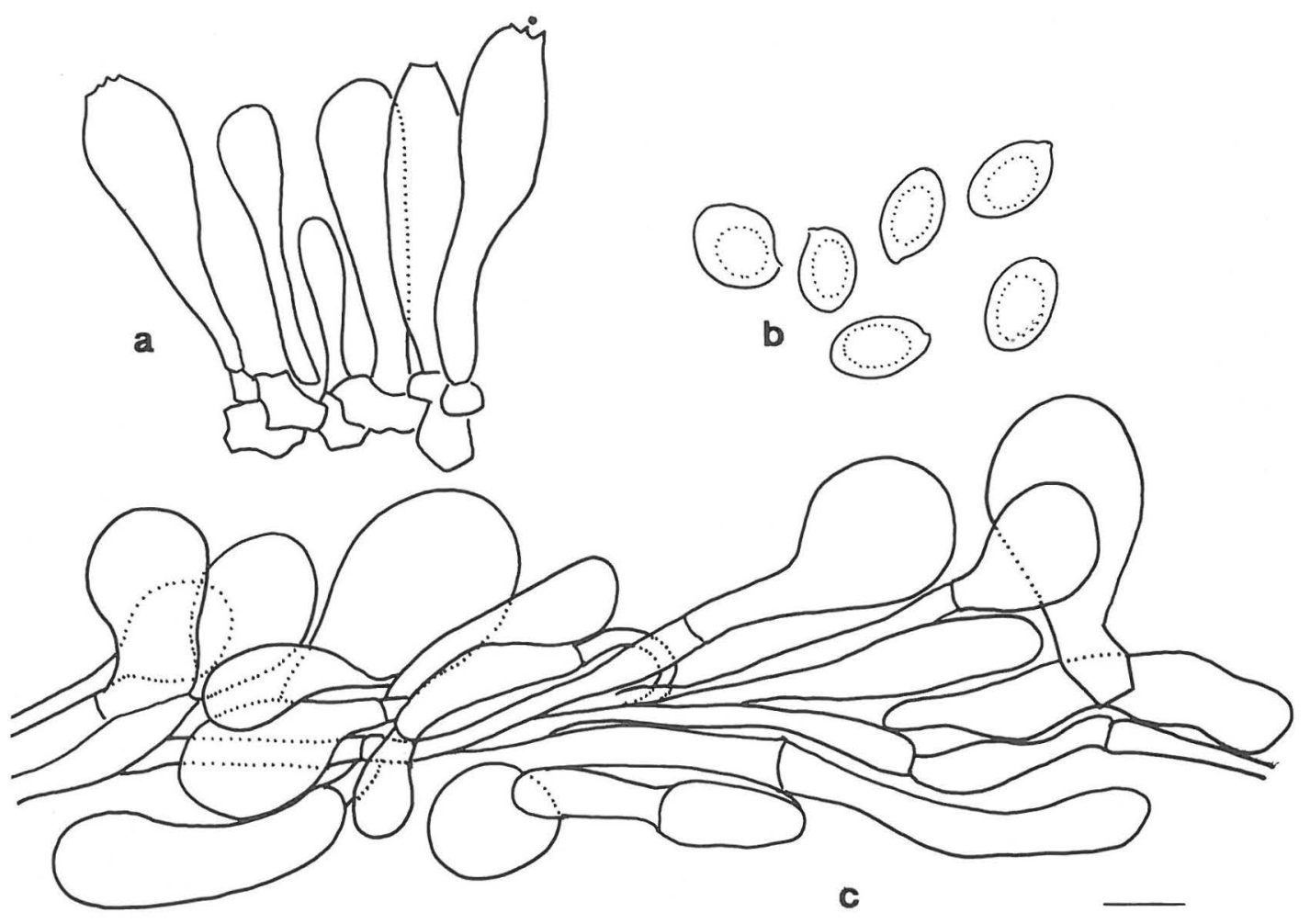

Fig. 7a-c. Amanita masasiensis (type). - a) hymenium, b) spores, c) tissue on sterile gill margin. Bar $=10 \mu \mathrm{m}$.

Type: Tanzania. Southern Highlands Prov.: Iringa Distr., Mafinga, Changarawe village (08 35 AD), degraded miombo woodland dominated by Uapaca, $1750 \mathrm{~m}$, 5.II.1993 Saarimäki et al. 1577 (holotype, H).

Pileus $4-13 \mathrm{~cm}$ in diameter, convex to flat, copper-brown to chestnut, surface silky, smooth, sticky, striate $1-1.5 \mathrm{~cm}$ from margin towards centre. Lamellae free, fairly crowded and fairly thin, from ivory to yellow, $10-14 \mathrm{~mm}$ wide, smooth at edge. Stipe 5-11 $\times 1-2 \mathrm{~cm}$, cylindrical, from very pale yellow to yellow, above ring striate, below ring floccose. Annulus superior, hanging, thin, finely plicate, pale yellow, in some specimens turning greyish and fugacious. Volva attached to extreme point of stipe, white to greyish, big, saccate, lobed, thick, slightly floccose outside, smooth inside with a small limbus internus. Context in cap white, firm, under pellicle yellow, in stipe white, brittle-fibrous, hollow. Smell weak, cellar-like. Taste mild. Spore print white.

Spores hyaline, inamyloid, ellipsoid to elongate, smooth, with one big guttule, 9.5-10.55-13 $\times 5.5-\underline{6.87}-8.5 \mu \mathrm{m}, \mathrm{Q}=1.44-1.53-66$. Basidia 4-spored, club-shaped, 30-50 × 9-12 $\mu \mathrm{m}$. Subhymenium of irregularly subglobose to angular cells, 5-15 $\mu \mathrm{m}$ in diameter. Gill margin sterile, marginal cystidia-like cells 30-75 $\mu \mathrm{m}$ in length. Surface of pileus strongly gelatinized in its upper part with fading repent hyphae underneath and with conspicuous vascular hyphae up to $17 \mu \mathrm{m}$ in diameter. Stipe trama at surface of rather robust, long, parallel cells, $2-8 \mu \mathrm{m}$ in diameter, several with clamps and some with club-shaped inflated endings up to $25 \mu \mathrm{m}$ in diameter; inside with loose and flexuous hyphae with inflated and club-shaped scells up to $65 \mu \mathrm{m}$ wide. Vascular hyphae numerous. Volva strongly gelatinized inside, outside of interwoven hyphae 3-5 $\mu \mathrm{m}$ in diameter, several with clamps. Annulus totally or partially gelatinized or of interwoven hyphae with many inflated club-, or pear-shaped cells.

Etymology: The epithet mafingensis refers to Mafinga, the collection site of the type material in Tanzania. 


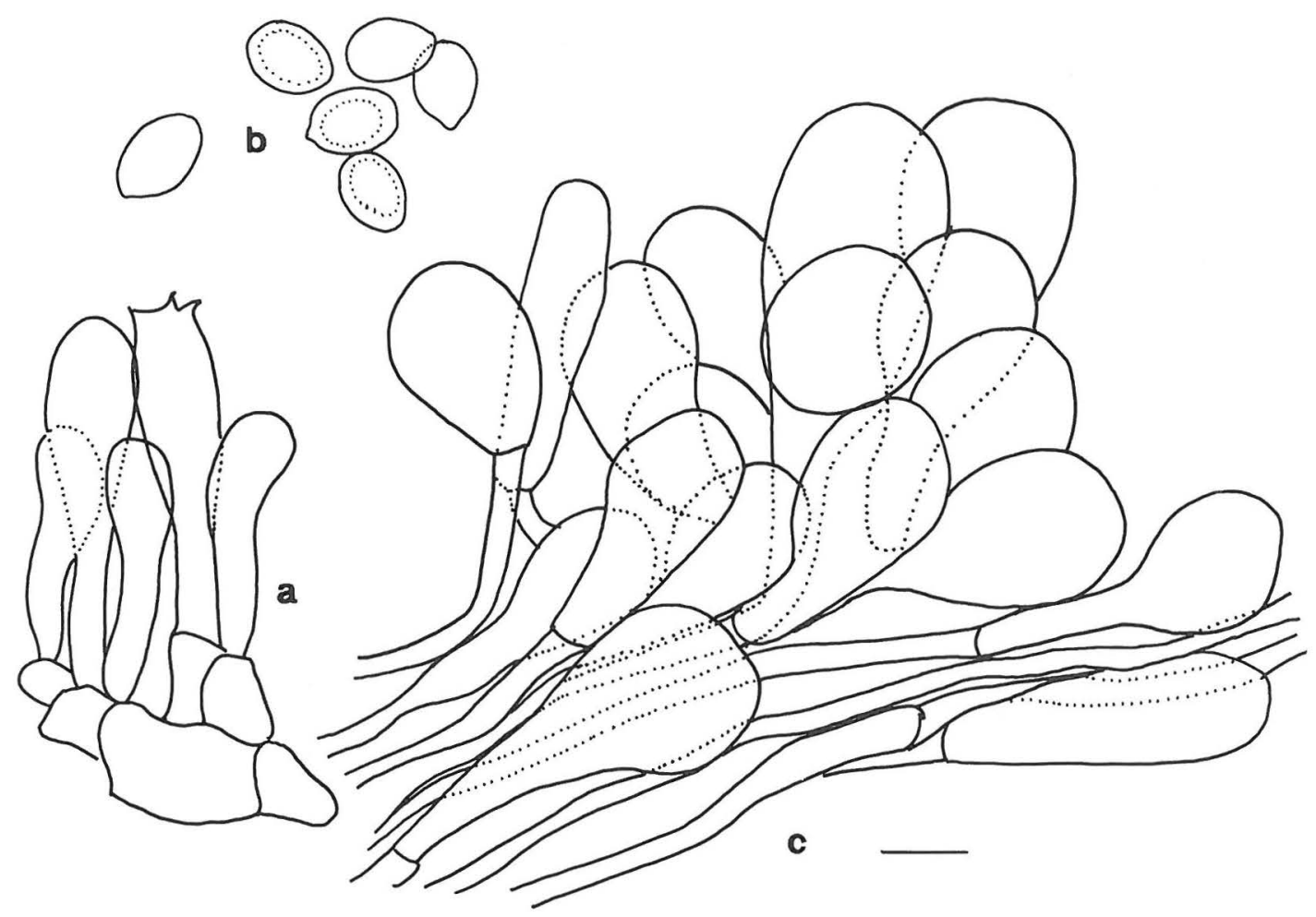

Fig. 8a-c. Amanita mafingensis (type). - a) hymenium, b) spores, c) tissue on sterile gill margin. Bar $=10 \mu \mathrm{m}$.

Ecology. Miombo woodland on a high plateau at an elevation of 1 000-1500 m. Evidently mycorrhizal with many miombo trees of which Brachystegia and Uapaca were most often present.

Specimens examined

Tanzania. Southern Highlands Prov.: Njombe Distr., 2 km $\mathrm{N}$ of Kidugala, Ngaramiro village (09 $34 \mathrm{BA})$, degraded Brachystegia-Uapaca woodland with Ochna, Parinari, Rothmannia, Combretum molle, Garcinia, and Gardenia, on hill slope, red soil, 1550 m, 31.I.1993 1476. Njombe Distr., N of Kidugala, between villages of Sengele and Masaulwa (09 34 BA), heavily grazed and degraded Brachystegia-Uapaca woodland, 1500 m, 2.II.1993 1527. Iringa Distr., holotype $1577 ; 40 \mathrm{~km}$ NE of Iringa, Itagutwa village (07 35 DA), degraded Brachystegia-CombretumAlbizia woodland, $1300 \mathrm{~m}$, 8.II.1993 1597; $65 \mathrm{~km}$ E of Iringa, Ikokoto village (07 $36 \mathrm{CA}$ ), Brachystegia woodland with few Uapaca, Protea, Hymenocardia, and Combretum, rocky outcrops, sandy soil, 1050 m, 9.II.1993 1615.

\section{Discussion}

The brilliant colours of the Tanzanian specimens have faded in their dried state, with the white colour of the gills and stipe no longer so pure. The specimens of Amanita hemibapha from Southeast Asia sent by Bas are somewhat faded as well. From the color plates of Berkeley and Broome (1871) and Corner \& Bas (1962) and from the colour photographs of fresh specimens kindly sent to us by Bas we could see the striking colours of fresh A. hemibapha.

All the Tanzanian specimens differed macroscopically from Amanita hemibapha in having no fibrillose-scaly, bright coloured zones on the stipe and having no gills with a yellow margin. On the contrary, under a dissecting microscope the gill margins of the dried specimens were covered with loose white tissue. A. tanzanica had no yellow colour either on the stipe, on the gills or on the annulus. 


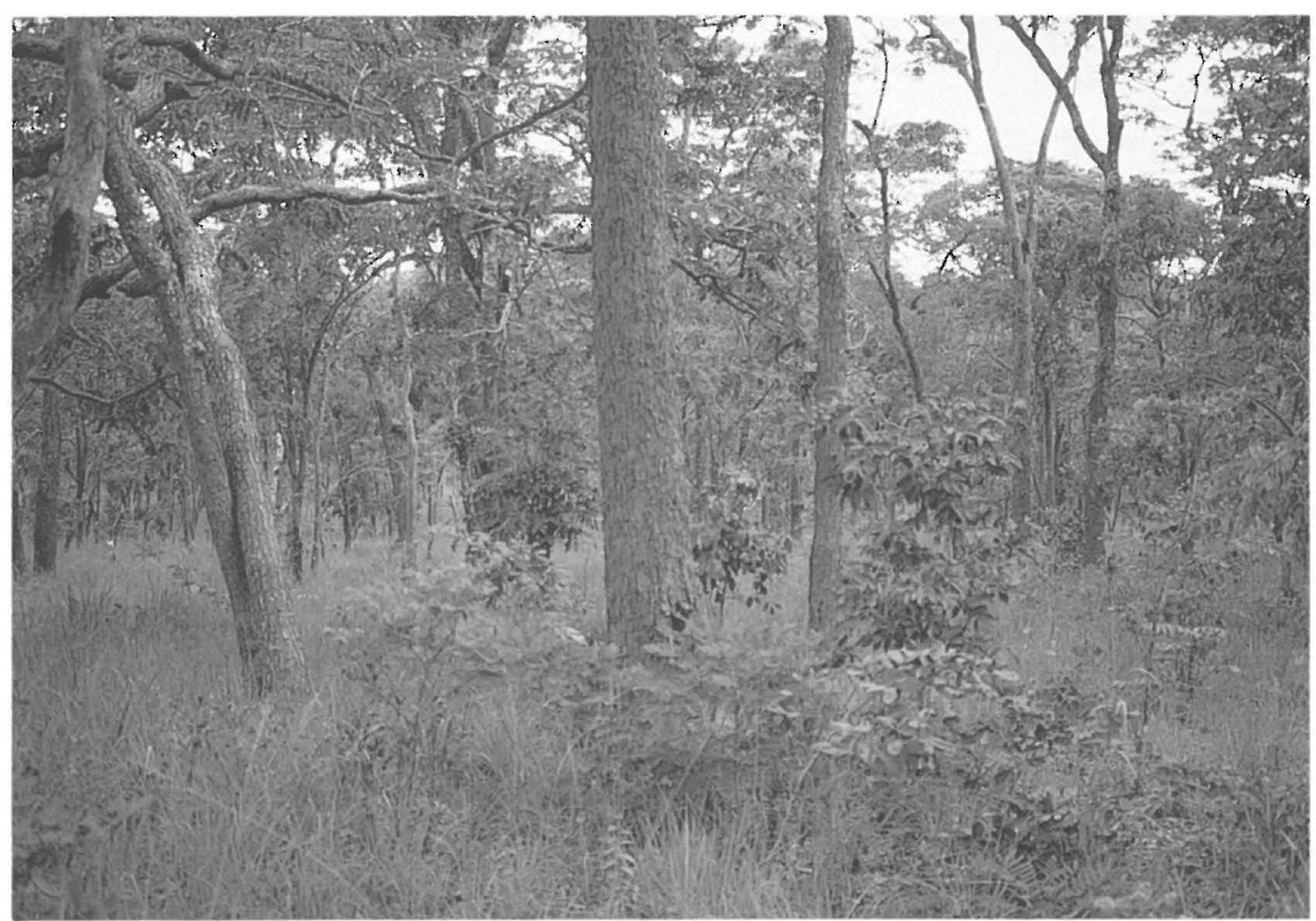

Fig. 9. Natural miombo woodland in Songea, rich in mushrooms.

Amanita masasiensis, with its orange-yellow pileus and bright yellow stipe, ring, and gills, resembled macroscopically $A$. hemibapha subspecies javanica, but microscopically it was closer to $A$. tanzanica.

Amanita mafingensis, with its brown pileus and pale yellow gills, stipe, and ring, was macroscopically the most heterogenous, some specimens having a greyish ring and volva, some having a white volva and yellow ring. In colour it resembled A. robusta Beeli (see Gilbert 1941b: tab. 13). This species, however, has a bulbous base, an evanescent ring and much smaller spores (Gilbert 1940, 1941a). Morris (1987: pl. 1) presents a colour drawing with the name $A$. bingensis Beeli which shows a reddish brown cap, yellow gills, and a pale yellow stem and ring. Gilbert's (1941b: tab. 19) color plate of $A$. bingensis looks very different from the latter, whereas Morris's picture looks more like our A. mafingensis, although the written description does not fit it. The name Nakajongolo, which Morris collected from the Yao in Malawi as the species he calls $A$. bingensis, is the same that we picked up from the Yao in Tanzania as A. tanzanica and A. masasiensis.

Microscopically the main difference between the Tanzanian material and Amanita hemibapha is the size and shape of the spores, which are smaller and more globose in A. hemibapha (length/width ratio $\mathrm{Q}=1.2$ ) than in the Tanzanian specimens (on average $Q=1.5$ ). According to Bas (1977) the spore size and most of all the length/width ratio are the most essential and constant features in the microscopy of section Vaginatae. During our microscopical examinations we first believed we were seeing cystidia at the gill margins. However, according to Bas (1977), cystidia are lacking in the genus Amanita, and the cystidia-like cells of the marginal tissue are remnants of the partial veil. After more thorough examination we can verify that these inflated cells never arise from the underlying gill trama. In the Tanzanian specimens there is no yellow sap in the cells of the gill margin as mentioned by Corner \& Bas (1962) for $A$. hemibapha. We could find no such sap in the dried specimens of that species either, but possibly the colour has faded, as the specimens are over 30 years old. According to Corner \& Bas (1962) the 


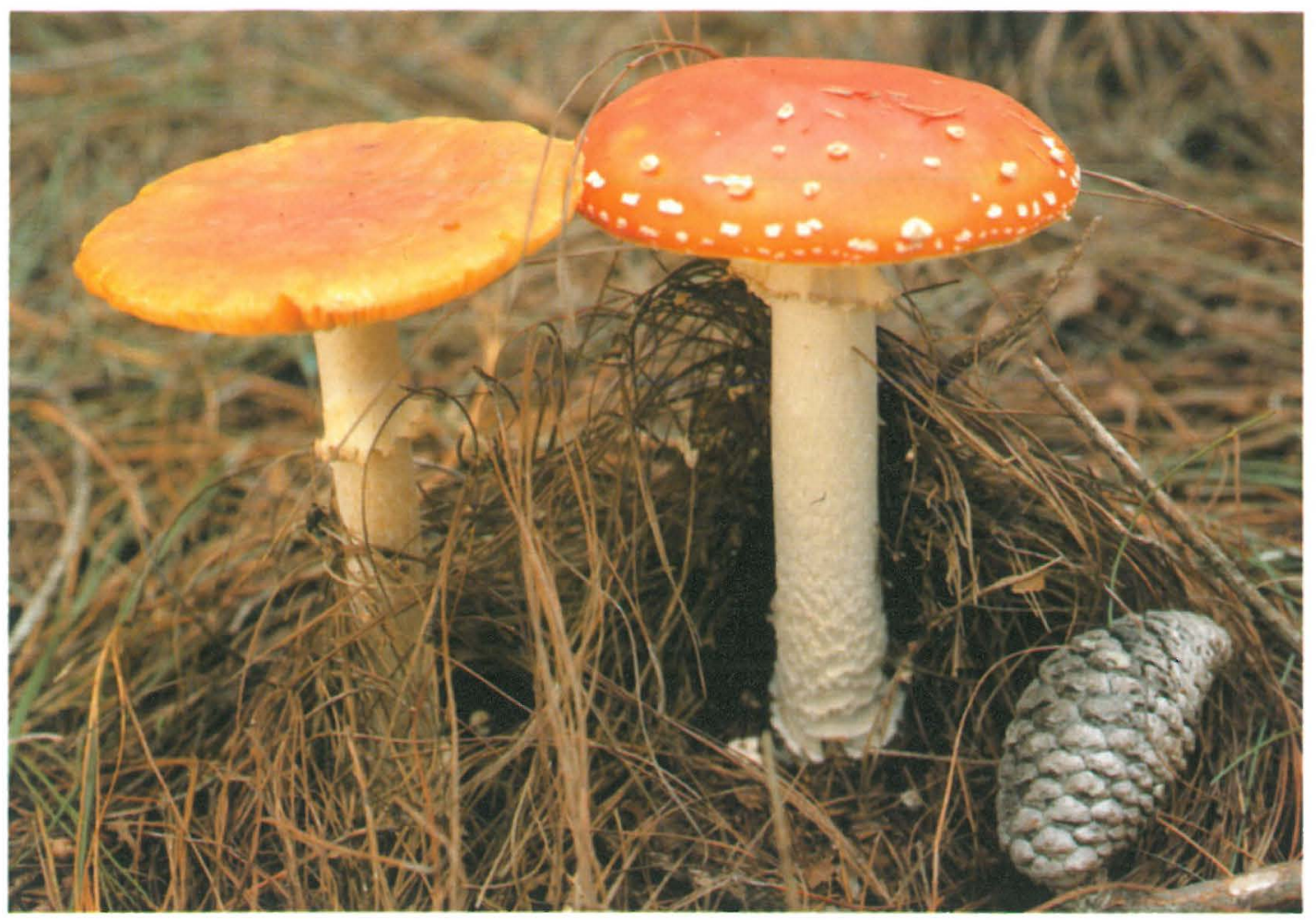

Fig. 10. Amanita muscaria pushing up through weakly decomposed Pinus patula litter. A pale Amanita muscaria (on the left) which has lost its velar remnants from the pileus surface very much resembles edible Amanita species described here.

outer layer of the volva, at least in subsp. similis, has more or less longitudinal hyphae and an inner layer which is composed of up to $90 \mu \mathrm{m}$-wide inflated cells mixed with thin hyphae. We could easily find such cells in the Indian material from Uttar Pradesh (Bas 4270). In the Tanzanian material the outer layer comprised interwoven hyphae, and the inner layer was strongly gelatinized without inflated cells.

There were no distinct microscopical differences between the three Tanzanian species, but their colour variation was so striking that we could easily recognize them in the field. In general appearance Amanita masasiensis is the most delicate and $A$. mafingensis the most robust species.

\section{Comparison material examined}

Amanita caesarea

Romania. Buteni, Arad, ad terram in quercetis, alt. $250 \mathrm{~m}$, 18.VII.1964 M.Toma (H).

Amanita hemibapha

Canada. Québec, near Québec, 1951 Pomerleau 84885 (under the name Amanita caesarea, but indentified by Bas as A. hemibapha s.lato) (L).
India. Uttar Pradesh, near Rajspur, $\pm 8 \mathrm{~km} \mathrm{~N}$ of Dehra Dun, 1964 C. Bas 4270 (L). Japan. Yamanashi Pref., Mt Fuji, Shojin-guchi, 1983 C.Bas 9028 (L). U.S.A. Tennessee, Knoxville, 1934 Hesler 7192 (L).

Amanita hemibapha subsp. similis

Malaysia. Johore, Gunung Panti, 1929 Corner (L). Singapore. Singapore, Bukit Timah, 1939 Corner (L).

\section{Vernacular names}

Swahili, one of the more than 300 Bantu languages, together with English, are the two official languages in Tanzania. The common Swahili term for mushroom is uyoga, used as a collective noun having no singular or plural concept.

The Amanita species described in this article do not have Swahili names because the language has its origin at the coast, and the specimens were collected in central and southern parts of Tanzania where other Bantu languages are spoken. It seems that also in other Bantu languages mushrooms belong to the noun class of collective words. 


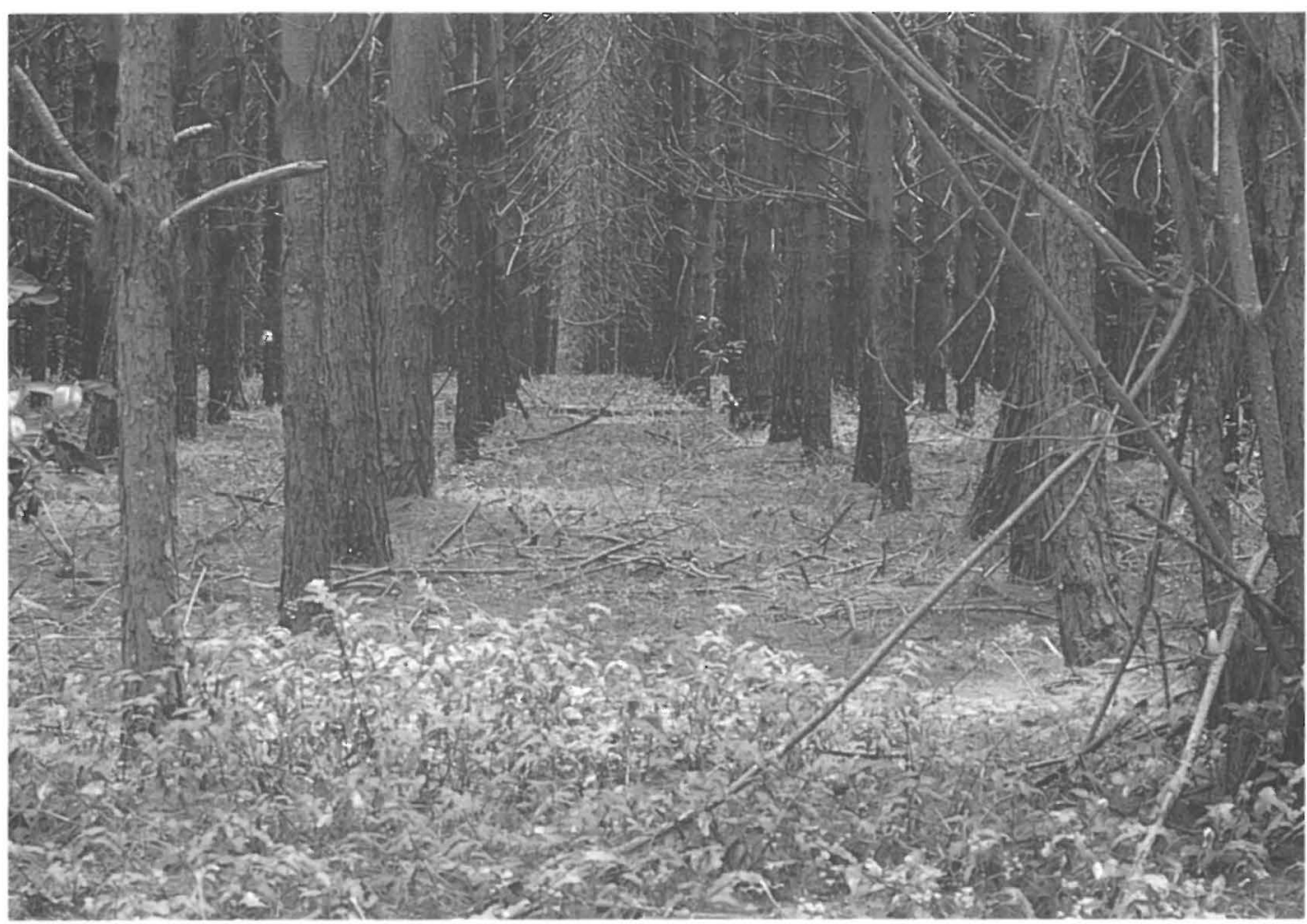

Fig. 11. Former miombo woodland in Mufindi taken over by Pinus patula plantation, rich only in Amanita muscaria.

People from different tribes whom we had discussions with had a name of their own for these Amanitas, but always it was a collective one for all the three species and included even some reddish Amanitas without an annulus. At least in the Hehe and Bena language this name originates from the striate margin of the pileus and refers to a millipede. When we purposely showed people white- and yellow-gilled specimens they stated that indeed there are different variations of this mushroom.

The following names were collected:

Ungongoli, Ugongolia, Unyangongolya, Wigongoli (Bena language); Wigwingwi (Hehe and Sangu languages); Nakajete, Wongolo (Makonde language); Kakongolo, Nakakongoro, Ung'ongoro, Ukongoro (Ndendeuli language); Ugongoro (Ngoni language); Unongonongo (Nyamwezi language); Nagayongolo, Nakajongole, Nakajongoo (Yao language).

Following the proposal of J. Makwetta (Minister of Agriculture of Tanzania) we suggest that
Wigwingwi be adopted as the common, swahilicized name for these edible species of reddish Amanita.

\section{Edibility}

We often found specimens of these tree Amanitas in the baskets of women who were returning from mushroom hunting. Some people of the Bena, Hehe, Makua, and Makonde tribe eat only the cap; the stipe is already cut off in the field. In the course of the interviews when we showed the interviewee specimens collected by ourselves, the first thing she did was break off the stem and throw it away. This is exceptional, since usually Tanzanians eat all parts of edible mushrooms. People could not explain why they consume only the cap; it is an ancient habit. Astonishingly, in Nepal the people of a TibetoBurman tribe reject the volva of the local edible mushroom, A. chepangiana Tullos \& Bhandary (Tulloss \& Bhandary 1992). Maybe this habit originates from the experience of their ancestors. It has 
been shown that, at least in A. phalloides (Fr.) Link, the volva has the highest concentrations of poisonous substances (Enjalbert et al. 1989).

Some Tanzanians, at least Makonde people, parboil these Amanitas, but most people cook them straight away. They are never eaten raw. When we asked people to estimate the deliciousness of these species on a scale from 1 to 3 , most people gave them two or three points.

People do not usually preserve mushrooms of the Amanita tanzanica group. We never saw them spread on the mats on which representatives of Lactarius, Russula and Cantharellus were sundried.

\section{Confusion with Amanita muscaria}

Tanzanian savanna woodland, the miombo (Fig. 9), is rich both in tree species and mycorrhizal mushrooms. Many species of Amanita, including ones other than those described here, are present, and many of them are eaten by local people. The people we interviewed had no traditional knowledge of poisonous Amanitas.

Hardly any untouched miombo woodland can now be found as it has been used for agricultural purposes from time immemorial, trees are periodically cut and burnt for agricultural purposes. After some years of cultivation the fields are abandoned. Tree stumps recover and sprout easily, and soon miserable-looking stunted trees support a rich yield of mushrooms.

Since colonial times the woodlands have also become the object of even more irreversible management. Large areas have been taken over by plantations of exotic trees, for instance Pinus and Eucalyptus (Fig. 11). This cultivation is useless to the local people. It yields neither wild vegetables nor edible fruit as miombo does, and no grass for cattle to graze. There seems to be a shortage of decomposing fungi as well. Contrary to the situation in natural forests, the litter accumulates to form a thick layer of several centimeters (Fig. 10).

Not only has the white man's activity destroyed the yield of local mushrooms, but exotic mycorrhizal fungi have been introduced. In February 1993, in Mufindi, Sao Hill, and Mafinga in the Iringa region, we could see Pinus patula and $P$. caribaea plantations full of the common Amanita muscaria mushroom (Fig. 10). The plantations originate from the 1960's (personal inquiries made by L.Mwasumbi). A. muscaria was apparently in- troduced by accident, since soil of old Pinus plantations were needed to make the plantations flourish.

This situation is dangerous, as the Tanzanians are used to consuming a large variety of Amanita species. During the interviews we held, it became evident that mushroom poisonings, even fatal ones, occur quite often. African families just pick the traditional mushrooms and reject all the others. They make no effort to identify inedible fungi.

In Mafinga we visited a hospital where some patients suffering from mushroom poisoning had just been taken. Later we could trace the species and the habitat of the mushroom involved. It turned out to be A. muscaria growing under some scattered Pinus patula trees along a path in a near-by village. The patients told us that they had believed it to be Wigwingwi. The food made of it was good and had mild taste. After a couple of ours the two women and a child who had eaten it began to feel sick, but they did not vomit. Very soon they lost consciousnes and began to hallucinate. One of the women could see her dead relatives and could talk with them. The other imagined that she went to a church which was full of people, all women, and she felt herself very uncomfortable. Later she was left alone in the church with all the doors locked and was very much afraid. We assured the doctor and the patients that this kind of psychotropic poisoning does not usually have fatal consequences. Unfortunately, one of the women did die the following night.

After these experiences we understand how essential it is to the Tanzanian rural people to save the natural biodiversity of the forests. Now, when Amanita muscaria has already become naturalized in the tree plantations, a full information program should be arranged to warn people of the dangers of this poisonous mushroom.

Amanita muscaria seems to be a popular object of mycorrhizal investigations and has proved to be an effective symbiont which stimulates the growth of pine seedlings (see e.g. Marais \& Kotzé 1977 and Stenström \& Ek 1990). Let us hope that no standard method will be developed to inoculate pine seedlings with $A$. muscaria for forest plantations, at least not in Tanzania, where red species of Amanita are considered edible. More suitable for that purpose would be for instance Suillus granulatus (L. : Fr.) Roussel. We have seen also this species in pine plantations in Tanzania, but people never use it for food. 
Acknowledgements. We wish to thank Dr. C. Bas (Rijksherbarium Leiden) for the loan of material of Amanita hemibapha and the critical reading of the manuscript. We are grateful to Mr. Heino Vänskä, Lic.Phil. (Helsinki) for the Latin descriptions of the species. Prof. Arvi Hurskainen (Department of Asian and African Studies, University of Helsinki) revised the orthography of the vernacular names. The following persons took part and aided in different collecting trips: Prof. Tuomo Niemelä, Ms. Sanna Laaka, Lic.Phil., and Mr. Kalevi Härkönen, Technician. The Finnish International Development Agency (FINNIDA) funded the research. Dr. Carol Norris revised the English text.

\section{References}

Bas, C. 1969: Morphology and subdivision of Amanita and a monograph of its section Lepidella. - Persoonia 5: $285-579$.

Bas, C. 1977: Species concept in Amanita sect. Vaginatae. - Bibliotheca Mycologica 61: 79-103.

Berkeley, M. \& Broome, C. 1871: On some species of the genus Agaricus from Ceylon. - Trans. Linn. Soc. London 27: 149-152.

Corner, E.J.H. \& Bas, C. 1962: The genus Amanita in Singapore and Malaya. - Persoonia 2: 241-304.

Enjalbert, F., Cassans, G. \& Andary, C. 1989: Variation in amounts of main phallotoxins in Amanita phalloides. - Mycologia 81: 266-271.

Gilbert, E.J. 1940: Amanitaceae 1. In: Bresadola, J. (ed.), Iconographia Mycologica 27 (Suppl. 1): 1-199. Comitato Onoranze Bresadoliane, Mediolani.

Gilbert, E.J. 1941a: Amanitaceae 2. In: Bresadola, J. (ed.), Iconographia Mycologica 27 (Suppl. 1): 203-425. Comitato Onoranze Bresadoliane, Mediolani.

Gilbert, E.J. 1941b: Amanitaceae 3 (Tabulae). In: Bresadola, J. (ed.), Iconographia Mycologica 27 (Suppl. 1): 1-73. - Comitato Onoranze Bresadoliane, Mediolani.
Härkönen, M. 1992: Wild mushrooms, a delicacy in Tanzania. - Univ. Helsingiensis 12: 29-31.

Härkönen, M., Buyck, B., Saarimäki, T. \& Mwasumbi, L. 1993a: Tanzanian mushrooms and their uses 1. Russula. - Karstenia 33: 11-50.

Härkönen, M., Saarimäki, T. \& Mwasumbi, L. 1993b: Tanzanian mushrooms and their uses 2. An edible species of Coprinus section Lanatuli. - Karstenia 33: 51-59.

Härkönen, M., Saarimäki, T., Mwasumbi, L. \& Niemelä, T. 1993c: Collection of the Tanzanian mushroom heritage as a form of developmental cooperation between the Universities of Helsinki and Dar es Salaam. - Aquilo Ser. Bot. 31: 99-105.

Jenkins, D.T. 1986: Amanita of North America. - 198 pp. Mad River Press, Eureka

Leistner, O. \& Morris, J. 1976: Southern African place names. - Annals Cape Prov. Mus. 12: 1-565.

Marais, L.J. \& Kotzé, J.M. 1977: Notes on ectotrophic mycorrhizae of Pinus patula in South Africa. - S African For. J. 100: 61-71.

Morris, B. 1987: Common mushrooms of Malawi. - 108 pp. Fungiflora, Oslo.

Polhill, D. 1988: Flora of East Tropical Africa. Index of collecting localities. - 398 pp. Royal. Bot. Gardens, Kew.

Saarimäki, T., Härkönen, M. \& Mwasumbi, L. 1994: Tanzanian mushrooms and their uses 3. Termitomyces singidensis, sp. nov. - Karstenia 34: 13-20.

Singer, R. 1975: The Agaricales in modern taxonomy. 912 pp. Cramer, Vaduz.

Stenström, E. \& Ek, M. 1990: Field growth of Pinus sylvestris following nursery inoculation with mycorrhizal fungi. — Canadian J. For. Res. 20: 914 918.

Tulloss, R.E. \& Bhandary, H.R. 1992: Amanita chepangiana, a new species from Nepal. Mycotaxon 43: 25-31.

Received on 25 March 1994 